\title{
Geothermal flux and phreatic speleogenesis in gypsum, halite, and quartzite rocks
}

\author{
Giovanni Badino* \\ Department of Physics, University of Torino, Via P. Giuria 1, 10125 Torino, Italy \& Associazione La Venta
}

\begin{abstract}
The first layers of rock underground are in thermal contact with the external atmosphere mainly through infiltrating meteoric water. This relatively cool zone absorbs rising geothermal energy, which heats the water. If the aquifer consists of gypsum, halite or quartzite, the water at those depths is usually salt-saturated, so the increase in temperature renders the water aggressive again. This in turn leads to rock dissolution and formation of phreatic conduits. This way, the geothermal flow creates caves that do not necessarily reach the surface. This paper analyzes the speed of the excavation, which, in different types of rocks, depends only slightly on temperature and meteoric precipitation. The time scale of this speleogenesis appears to be similar to that of other known cave systems. These processes are probably able to greatly increase the permeability around underground radioactive waste storage in halite.
\end{abstract}

Keywords: geothermal flux, phreatic speleogenesis, hypogenic caves, evaporite, quartzite, radioactive waste storage

Received 4 December 2016; Revised 19 July 2017; Accepted 24 October 2017

Citation: Badino G., 2018. Geothermal flux and phreatic speleogenesis in gypsum, halite, and quartzite rocks. International Journal of Speleology, 47 (1), 1-11. Tampa, FL (USA) ISSN 0392-6672 https://doi.org/10.5038/1827-806X.47.1.2098

\section{INTRODUCTION}

Rocks below the Earth's surface have temperatures that increase with depth. The geothermal energy flux in the upper few dozens of kilometers of the Earth's crust is described by the usual thermal conduction equations. The resulting temperature gradient depends on the local rock conductivity, but it has an average value around $25-30^{\circ} \mathrm{C} / \mathrm{km}$. This energy flux is small, and plays no role in heating the Earth's atmosphere. At first, its effect in caves appears to be negligible because, unlike mines, these environments are usually quite cold, essentially at the external mean-annual temperature. This work attempts to show that geothermal energy can heat deep water, increasing the solubility of gypsum, halite, and quartzite, and thus forming caves.

\section{The geothermic intensity flux}

The geothermal flow through oceanic crust is not relevant here. However, the global average of continental heat flow is (Davies, 2010):

$$
F_{g t}=0.07 \mathrm{Wm}^{-2}
$$

This corresponds to a total flux of $4.6 \times 10^{13} \mathrm{~W}$ for the whole planet. The solar power received on Earth is
$1.8 \times 10^{17} \mathrm{~W}$, which makes the geothermal contribution about 4000 times smaller.

Underground temperature begins its geothermal heating well below the surface (hundreds or thousands of meters, as shown below), because in the upper layers the infiltration of meteoric water forces the rock to assume its average temperature, which is essentially the average local yearly surface temperature (Badino, 1995). The consequence is obvious: geothermal energy does not flow through these upper layers, as deep-flowing water completely intercepts the meteoric infiltration and carries it away at the base of the infiltration zone (Mathey, 1974).

The thickness of this shielded stratum depends on the local rock permeability. In a non-karstic environment, it is usually around 50-100 meters, but it can be much greater along major rock discontinuities that are able to drain water, as observed during the excavation of the Mt. Blanc tunnel (Guichonnet, 1967). In deep karst, this "cold" layer usually includes the entire underground system (Badino, 2005), which extends at least 1-2 km below the surface (Sendra, 2012).

\section{Near-surface ground temperature}

It is possible to distinguish a top layer affected by daily temperature fluctuations, the "heterothermic 
daily layer", which in compact rock has a typical thickness of less than a meter. Seasonal temperature variations can penetrate 15-20 times deeper (the conductive penetration length of sinusoidal thermal alterations depends on the square root of the period; Isachenko, 1969), and this depth defines the "heterothermic seasonal layer" (Fig. 1). This layer is usually a few meters deep; over this distance, seasonal temperature variation decreases to zero, a condition which defines its lower boundary (heterothermichomotermic boundary, HHB) (Luetscher, 2004).

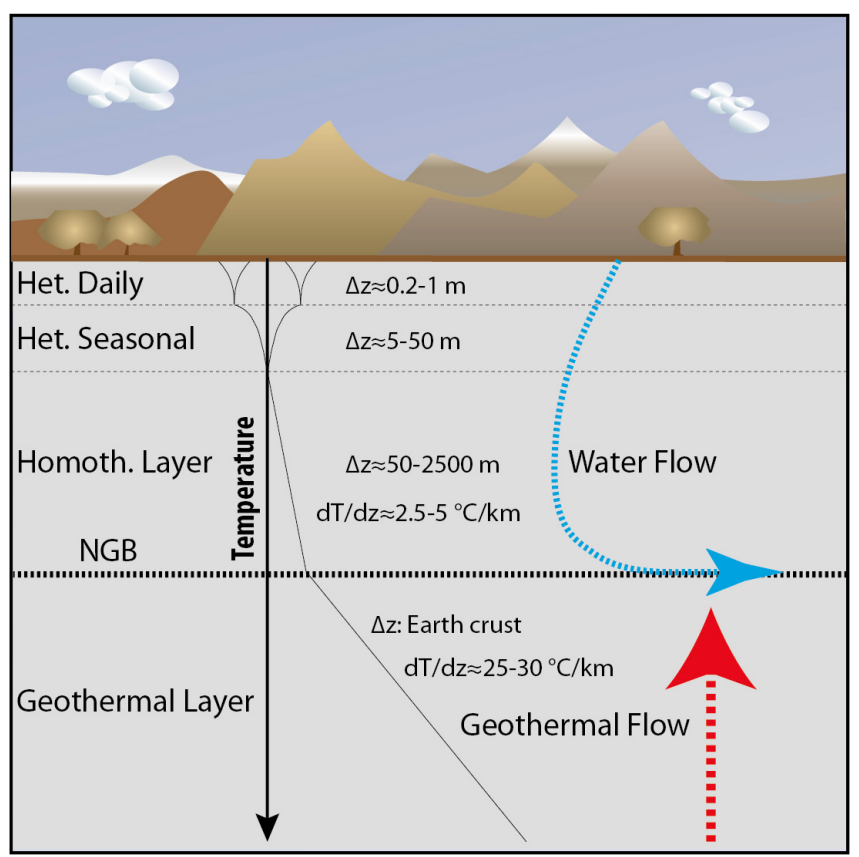

Fig. 1. Geothermal profile: Heterothermic layers, with daily and seasonal temperature ranges, Homothermic Layer at the average temperature of infiltrating water and a deep, undisturbed layer in thermal contact with deep rocks.

In permafrost studies, these two upper layers are called the "active layer" because here ice can be formed and melted, if weather conditions allow it (Shiklomanov, 2013).

Beneath the HHB, the rock assumes the average local temperature of infiltrating waters (hereafter indicated as $\mathrm{T}_{\mathrm{aw}}$ ). Infiltrating waters are usually a significant fraction of precipitation (Celico, 1986), which in temperate regions has a scale dimension of $1000 \mathrm{~kg} / \mathrm{m}^{2} /$ year. This means that on average the water that penetrates underground each year has the same thermal capacity as a one-meterthick rock layer. Hence, on a geological time scale, flowing water forces a rock layer, no matter how large, to thermal equilibrium.

The water temperature depends on the seasonal precipitation, i.e., on the regional climate, but it is usually close to the external yearly local average temperature $\mathrm{T}_{\text {ave }}$ (Badino, 1995). In karst studies, the rock layer (and its caves) beneath HHB, which is at constant temperature $\mathrm{T}_{\mathrm{aw}}$, has different names: "neutral zone" (Dublijanski, 1977), (Tikhomirov, 2016), "isothermal zone" (Crestani, 1939), and others. In this paper the term "homothermic zone" is used (as in Luetscher, 2004). This layer extends down in the water table up to the level where the flowing external water thermally prevails over the geothermal flux in establishing the rock temperature. This means up to the level where rock permeability is sufficiently high to permit a significant flux of external water to the springs, in the lower parts of the phreatic drainage system. This permeability horizon is the boundary between the homothermic and geothermal layer (HGB).

Below this level, rock and interstitial water (almost motionless here) are afflfected by the geothermal flux, and its temperature regularly increases by conduction, as shown above. In the absence of a general term, it is possible to call this zone the "geothermic layer"; it extends downward for kilometers, i.e., indefinitely for the present discussion.

\section{Physics of the homothermic layer}

The homothermic layer is thus enclosed between two surfaces, the boundary layer (HHB), where the yearly temperature variation is very close to zero, and the HGB, where the rock temperature starts to increase because of the local geothermal lapse rate. As noted above, HGB is essentially the level at which the rock permeability becomes too small to allow flow of water sufficient to subdue the geothermal flux. It is usually the lower part of the drainage zone, in other words a relatively thick horizon of fissures or, in karst, the floor surface of draining conduits. In this layer, flowing water subdues the rising geothermal flux, preventing it from reaching the upper rocks, while at lower levels the flow is so slow that water reaches thermal equilibrium with the surrounding hot rock.

An analysis of thermal exchange by dynamic similarity (Ishachenko, 1969) makes it possible to estimate that the temperature differences in this region have a scale dimension of 1-10 $\mathrm{mK}$ (millikelvins), which is experimentally undetectable. Therefore, sudden temperature changes through the HGB are not expected.

It is now possible to estimate the thickness of the homothermic layer, where flowing water dominates the thermal exchange. In sufficiently homogeneous underground environments (e.g., in poorly permeable material) most water infiltrates and flows below the surface for just a few dozen meters (Luetscher, 2004). In karst environments, however, this is not the case, because water can descend for great distances through the vadose zone. The homothermic layer may potentially comprise an entire mountain system; the deepest caves in the World (in Abkhazia) cross vertically through more than 2,000 meters of rock (Klimchouk, 2013), with a temperature increase of less than $5^{\circ} \mathrm{C}$ along the entire depth (Provalov, pers. comm.).

As noted above, infiltrating water in the homothermic layer has an essentially constant temperature $\mathrm{T}_{\mathrm{aw}}$. Its temperature is not independent of depth. In deep karst, air flow can also play a major role. Intersecting fluids undergo complex energy exchanges, increasing temperature along their decent through the homothermic layer at a typical "karstic" rate of $3-4^{\circ} \mathrm{C} / \mathrm{km}$ (Badino, 2010). This temperature increase with depth is much lower than the expected value in the case of heat exchanges between air and rock (around $5-6^{\circ} \mathrm{C} / \mathrm{km}$ ). It shows the dominant role of 
infiltration water in establishing the rock temperature (Luetscher, 2004). In contrast, the typical adiabatic lapse rate of descending groundwater is $2.34^{\circ} \mathrm{C} / \mathrm{km}$ (Badino, 1995).

\section{Increase in groundwater temperature}

Therefore, the upper levels (heterothermic and homothermic) above the HGB, are in thermal equilibrium with the external atmosphere, whereas the geothermic layer, below the HGB, is in thermal contact with the deep Earth's crust.

The geothermal energy $\mathrm{F}_{\mathrm{gt}}$, which flows through the deepest layer, meets the water mass (W) flowing just above the HGB and heats it. The basic hypothesis in estimating the geothermal effect on $\mathrm{W}$ is that, on average, the whole system $\mathrm{W}$ is under stationary conditions. The first law of thermodynamics states that the energy entering $\mathrm{W}$ from below is, on average, an enthalpy increase between its entry and exit points in $\mathrm{W}$. Thus it is possible to avoid considering the total mass of the aquifer and deal instead only with the outgoing flux. This "steady-state assumption" establishes that the system temperatures cannot change with time, at least on a yearly basis.

In this "black-box model", it is easy to estimate the water flux out of a region of surface area A. If the precipitation is $\mathrm{P}\left(\mathrm{kg} \mathrm{m} \mathrm{m}^{-2} \mathrm{~s}^{-1}\right)$, the infiltration $P_{i}$ is precipitation $P$ minus the water lost due to evaporation and external flows, a value that ranges from 30 and $40 \%$ in temperate regions, and up to $90 \%$ in deserts (Celico, 1986). Infiltrating water crosses the upper rock layers, which are in thermal equilibrium with past infiltration, the atmosphere, and the small temperature increases due to gravitation and thermal exchanges with internal airflows ("karstic lapse rate" described above). Water then continues its flow into the phreatic region $(\mathrm{W})$, where it intercepts the geothermal flow.

With this assumption, the enthalpy extracted from the system is $\mathrm{P}_{\mathrm{i}} \Delta \mathrm{T}_{\mathrm{gt}} \mathrm{A}$, where $\Delta \mathrm{T}_{\mathrm{gt}}$ is the water temperature increase in $\mathrm{W}$ along its flow through the saturated region.

Then, if $\mathrm{C}_{\mathrm{w}}$ is defined as the specific thermal capacity of water,

$$
F_{g t} A=P_{i} C_{w} \Delta T_{g t} A
$$

this allows the problem to be solved. The usual units for precipitation are $\left(\mathrm{mm} \mathrm{a}^{-1}\right)$, equivalent to $\left(\mathrm{kg} \mathrm{m}^{-2} \mathrm{a}^{-1}\right)$; it is then possible to modify the above equation to:

$$
\Delta T_{g t}=\frac{0.06}{4.2 \times 10^{3} P_{i}}=\frac{500}{P_{i}}\left[{ }^{\circ} \mathrm{C}\right]
$$

This value does not depend on total water mass or on flow velocity, but only on infiltration intensity. This means that the upper parts of a drainage systems (always included in the homothermic layer), are at $\mathrm{T}_{\mathrm{aw}}$, but when the water arrives at the bottom of its descent, near the HGB, it gets warmed up by $\Delta \mathrm{T}_{\mathrm{gt}}$ along its flow path to the springs (Fig. 2).

Therefore, in deep karst, water is heated as it travels along the path between the lowest parts of ponor caves and the springs. In conclusion, there is a small thermal disequilibrium between water in the caves and at the springs, due to geothermal energy absorption. In alpine karst, $\mathrm{P}_{\mathrm{i}}$ is around $1,000 \mathrm{~mm} / \mathrm{a}$, hence the average temperature increase of water is approximately $0.5^{\circ} \mathrm{C}$. In areas with low infiltration, the temperature increase can be many degrees; but if water infiltration is near zero, as happens in very arid areas, only the most superficial subterranean part (the heterothermic layer) interacts with the atmosphere by conduction, and the geothermal layer can move closer to the surface.

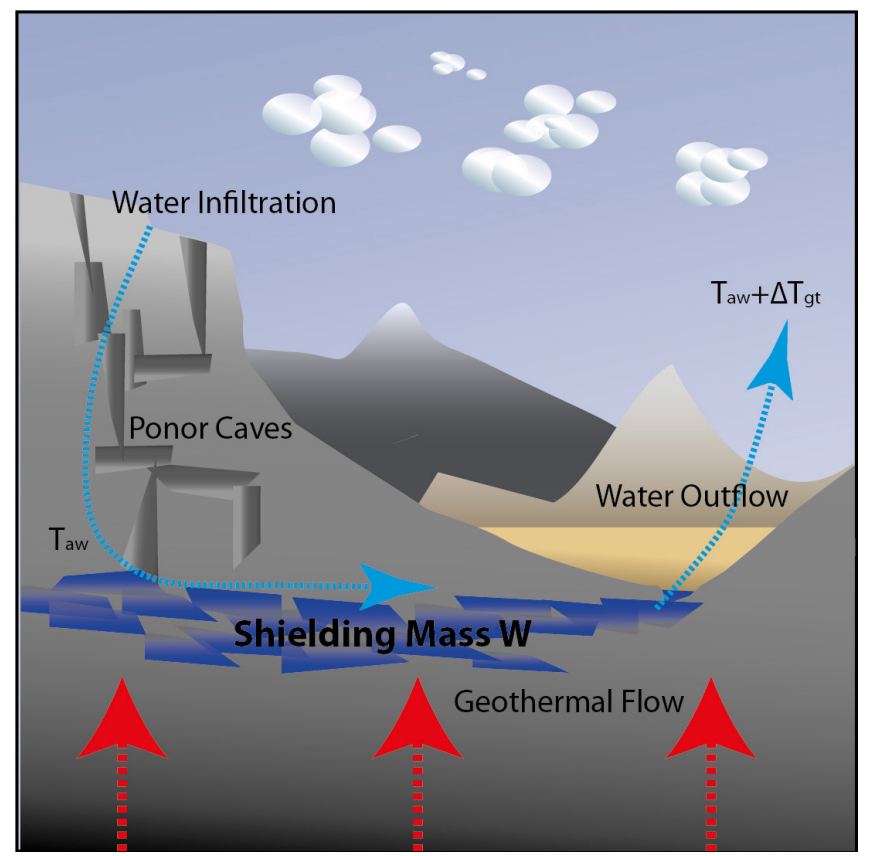

Fig. 2. Water infiltrates underground in vadose conduits, attaining thermal equilibrium with the rock of the homothermic layer. Flowing through the phreatic conduits, it absorbs geothermal energy and becomes warmer.

It should be emphasized that a trapped, non-flowing water body inside a cave system would not be involved in these processes, as its long-term absorption of geothermal flux would be zero because it would become part of the homothermic layer and would not interact with the geothermal flux.

If instead the water body lies in the geothermal layer, its temperature would reach equilibrium with the surrounding rock and would become "transparent" to the rising geothermal flux. Industrial excavation often intersects this type of water, usually called "mine waters": old, trapped, and hot. On a side note, this motionless groundwater probably represents more than $99 \%$ of liquid fresh water on Earth (Babkin, 2002), but it is not involved in the speleogenetic process described here.

\section{Structure of deep drainage systems}

The geothermal intensity is roughly homogeneous, which suggests that water heating varies with the geometry of the drainage network. On the one hand, it is reasonable to accept that a uniform aquifer, with homogeneous water flux, yields a uniform temperature rise as described above. However, in karst environments water flows in conduits; the general shape of the drainage system is far from uniform. One could thus expect that these "discrete", highly inhomogeneous conduit networks are able 
to intercept just a fraction of the geothermal flux collected by a continuous aquifer. In fact, if $\mathrm{S}$ is the total horizontal projection of drainage conduits, the energy released to the aquifer would appear to be $\mathrm{F}_{\mathrm{gt}} \mathrm{S}$. Nevertheless, it has been shown (Badino, 2005) that this is actually not the case, because in the long term the system reaches equilibrium, in which the shape of the geothermal field is completely modified by the presence of drainage conduits (Fig. 3). The underground temperature field $\mathrm{T}(\mathrm{x}, \mathrm{y}, \mathrm{z})$ is hence a solution of the Laplace equation:

$$
\nabla^{2} T(x, y, z)=0
$$

Functions that satisfy this condition are the "harmonic functions", common in many fields of physics (Nashchokin, 1979; Bejan, 1993). Note that harmonic functions are generally very smooth and regular. This means that even in the presence of a discrete drainage network, the temperature field around it, and consequently the energy released to it, are quite regular, without sudden changes. In other words, discrete structures can still intercept the total geothermal energy crossing the entire region.

In the cited work, it has been shown that the effective area of geothermal flux absorption of an underground structure (its "geothermal cross section") is not its geometric area, but is rather 10 times the conduit size multiplied by its depth, providing an intercepting surface enormously greater than the conduit's geometrical area, A. In other words, this "size increase" is due to the lensing effect created by the presence of cold fluids in the thermal field; the geothermal flux assumes a shape that "focuses" the energy flux onto the conduits (Fig. 3).

In conclusion, by applying the First Law of Thermodynamics, one can conclude that the temperature of water flowing underground invariably

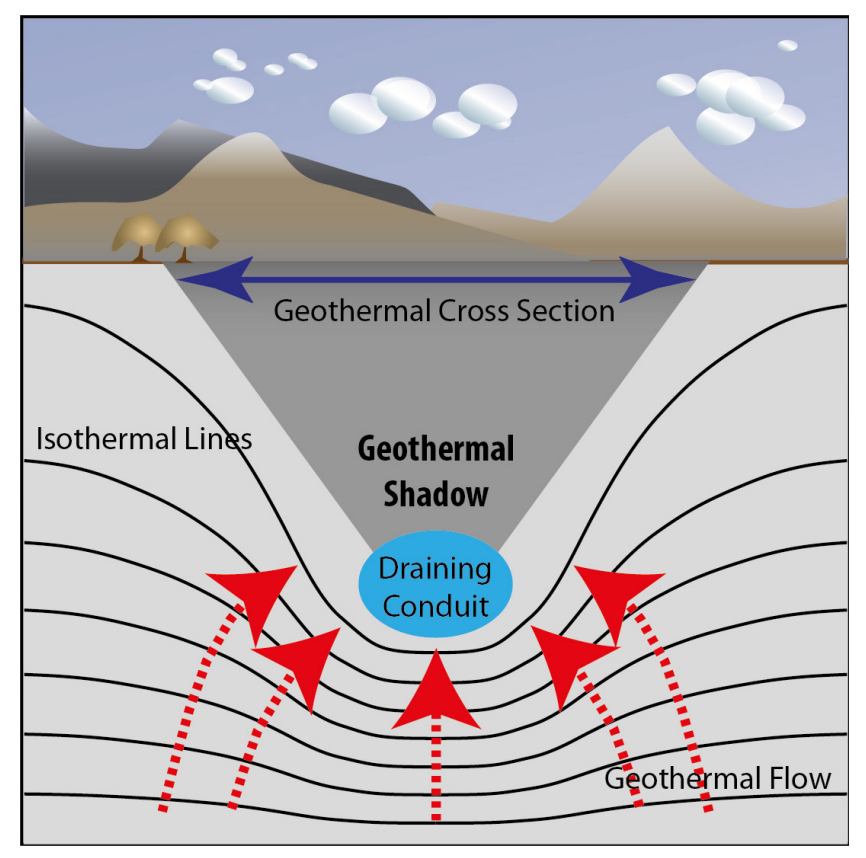

Fig. 3. Cross section of a draining conduit and isothermal lines around it. The presence of an underground drainage network changes the structure of deep thermal exchanges and focuses geothermal energy the "cold" conduits. The rock above the network is undisturbed and the "geothermal shadow" on the surface has a size comparable with the conduit depth. increases along its way to the springs as described by Eq. 1, regardless of the type and shape of the drainage system.

\section{GEOTHERMAL SPELEOGENESIS}

In soluble rocks, this heating creates an imbalance in the chemistry of salts already dissolved in the water, which in general had previously attained equilibrium along their subterranean flow path. In carbonate rocks the outcome is generally very complex, because the dissolution process depends on many phases and parameters (carbon dioxide solubility, closed or open system, etc.), and a specific, detailed study is required. On the other hand, there are rocks in which the temperature-solubility law is very simple, and it is possible to discuss these cases: gypsum, halite, and quartzite.

\section{Gypsum solubility}

Geothermal flow always increases the water temperature in the lowest part of the homothermic layer, so that it is necessary to calculate the temperature derivative $\mathrm{dc}_{\mathrm{x}} / \mathrm{dT}$ to obtain the solubilitytemperature dependence $\mathrm{c}_{\mathrm{x}}(\mathrm{T})$ of each rock. Gypsum solubility, measured in terms of calcium flux, depends on temperature according to the law:

$$
C_{C a}=-0,0602986 \mathrm{~T}_{\mathrm{c}}^{2}+5,65504 \mathrm{~T}_{\mathrm{c}}+507,332[\mathrm{mg} / \mathrm{kg}]
$$

where $\mathrm{T}_{c}$ is temperature in ${ }^{\circ} \mathrm{C}$ (Cohen, 1989). As a first approximation (the temperature change is here around $1^{\circ} \mathrm{C}$ ), it is possible to ignore second-order effects ( $\mathrm{pH}$, activity, etc.) and convert to total solubility of $\mathrm{CaSO}_{4} \cdot 2 \mathrm{H}_{2} \mathrm{O}$ by scaling it with the molecular weights of the gypsum and calcium $(\approx 172 / 40)$ as in (Klimchouk, 1996), so it becomes:

$$
C_{g}=-0,259037 \mathrm{~T}_{\mathrm{c}}^{2}+24.2935 \mathrm{~T}_{\mathrm{c}}+2179.45
$$

For example, at $\mathrm{T}_{\mathrm{c}}=15^{\circ} \mathrm{C}$ a gypsum-saturated water contains $2.48 \mathrm{~g} / \mathrm{L}$ of gypsum. The derivative of Eq. 2 gives the rate of change of solubility with temperature (Fig. 4), which is linear:

$$
\frac{d c_{g}}{d T_{c}} \approx-0.52 T_{c}+24.3[\mathrm{mg} / \mathrm{kg} / \mathrm{K}]
$$

This means that with a unitary temperature rise $\left(\Delta \mathrm{T}=1^{\circ} \mathrm{C}\right)$, gypsum saturated water can dissolve, in addition, almost $25 \mathrm{mg} / \mathrm{L}$ at $0^{\circ} \mathrm{C}, 13 \mathrm{mg} / \mathrm{L}$ at $20^{\circ} \mathrm{C}$ and $3 \mathrm{mg} / \mathrm{L}$ at $40^{\circ} \mathrm{C}$. At a temperature of $46.9^{\circ} \mathrm{C}$, Eq. 3 shows that $\mathrm{dc}_{\mathrm{g}} / \mathrm{dT}=0$, so the increase of gypsum solubility with temperature ceases: around this value, small temperature changes in either direction do not cause any dissolution or deposition.

Equation 1 shows that at higher temperatures $\left(>50{ }^{\circ} \mathrm{C}\right) \mathrm{dc}_{\mathrm{g}} / \mathrm{dT}$ becomes negative, and therefore the solubility decreases with temperature and water heating induces salt deposition. By combining Eq. 1 with Eq. 3 it is possible to estimate the dissolution per kilogram of flowing water (gypsum-saturated at the input) in the phreatic flow, due to geothermal heating:

$$
\Delta c_{g}=\left(\frac{d c_{g}}{d T}\right) \Delta T_{g t}=\left(-0.52 T_{c}+24.3\right) \frac{500}{P_{i}}
$$




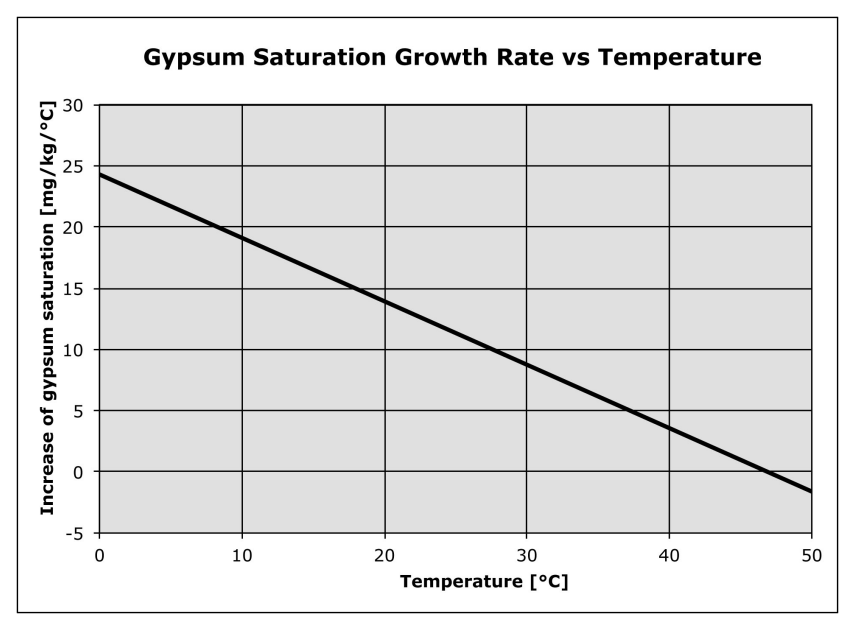

Fig. 4. Variation in calcium sulfate saturation level as a function of temperature.

With typical values $\left(\mathrm{T}_{\mathrm{c}}=15^{\circ} \mathrm{C}, \mathrm{P}_{\mathrm{i}}=1,000 \mathrm{~kg} \mathrm{~m} \mathrm{~m}^{-2} \mathrm{a}^{-1}\right)$ this equation yields a dissolution rate of about $8 \mathrm{mg} \mathrm{kg}^{-1} \mathrm{a}^{-1}$, which is the quantity of gypsum dissolved yearly per kilogram of underground flowing water that was initially gypsum-saturated.

Multiplying both sides by $\mathrm{P}_{\mathrm{i}}$, this equation gives the dissolution rate intensity per year:

$$
d_{g}\left[\mathrm{~g} \mathrm{~m}^{-2} \mathrm{a}^{-1}\right]=P_{i} \Delta c_{g}=-0.259 T_{c}+12.146
$$

This result can also be read as "kilograms of dissolved gypsum per square meter per thousand years", emphasizing that it is simply proportional to the geothermal flux multiplied by a temperaturedependent term (Fig. 5), and independent of precipitation. Using Eq.1:

$d_{g}\left[\mathrm{~kg} \mathrm{~m}^{-2} \mathrm{ka}^{-1}\right]=\left[\left(\frac{d c_{g}}{d T_{c}}\right) \frac{1}{C_{w}}\right] \times F_{g t}=-0.259 T_{c}+12.146$

It is possible to see that in cold regions the dissolution rate is about two times higher than in warm ones $\left(12.1\right.$ at $0^{\circ} \mathrm{C}$ and 7.0 at $20^{\circ} \mathrm{C}$ ), but also that the typical dissolution intensity induced by geothermal flux is around $10 \mathrm{~kg} / \mathrm{m}^{2} / \mathrm{ka}$.

It is appropriate at this point to discuss the role of enthalpy release when calcium sulfate dissolves in water. Its value (Newman, 1938) is $-33 \mathrm{cal} / \mathrm{g}$, which corresponds to $-138 \mathrm{~kJ} / \mathrm{kg}$ : so the process is exothermic, but the amount of released energy is small.

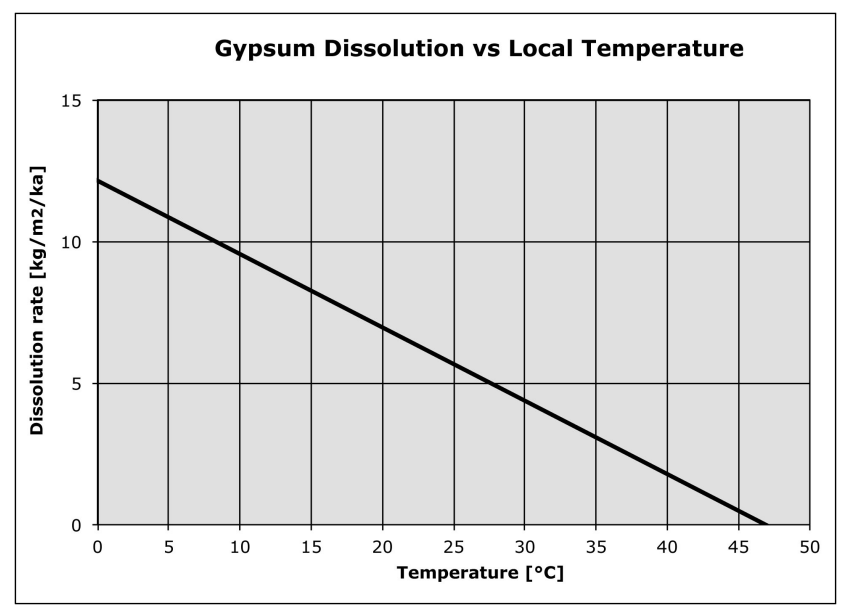

Fig. 5. Gypsum dissolution rate per square meter, as a function of HGB temperature.
Gypsum saturation of $1 \mathrm{~kg}$ of water at $15^{\circ} \mathrm{C}$ (shown above to be $2.48 \mathrm{~g} / \mathrm{kg}$ ) releases $343 \mathrm{~J}$, which causes a water temperature increase of just $81 \mathrm{mK}$. This is a very small value, which nevertheless affects the temperature fields along the saturation paths, usually along the heterothermic layer and then the homothermic layer. The enthalpy release along the last part of the underground path, in the HGB is obviously much smaller. Dissolution of $10 \mathrm{mg}$ of gypsum in one liter of water, caused by a $\Delta \mathrm{T}=1{ }^{\circ} \mathrm{C}$ increase at $8^{\circ} \mathrm{C}$, releases only $1.4 \mathrm{~J}$, which increases the system temperature by only $0.3 \mathrm{mK}$, which is completely negligible within these conditions.

\section{Quartzite and halite solubility}

The dependence of quartz solubility on temperature, $\mathrm{c}_{\mathrm{q}}$ (in $\mathrm{ppm}$ or $\mathrm{mg} / \mathrm{kg}$ ) is given by:

$$
\log c_{q}=-\frac{1176}{T_{\mathrm{c}}+273.15}+4.88
$$

where $T_{c}$ is centigrade temperature (Verma, 2000). The derivative of Eq. 6 gives the rate of change of quartz solubility with temperature (Fig. 6):

$\frac{d c_{q}}{d T_{c}}=\left[\frac{2708}{\left(T_{\mathrm{c}}+273.15\right)^{2}}\right] \exp \left(-\frac{2708}{T_{\mathrm{c}}+273.15}+11.2\right)[\mathrm{mg} / \mathrm{kg} / \mathrm{K}]$

A linear interpolation of this equation in the temperature range relevant for karst geology $\left(0<\mathrm{T}_{\mathrm{C}}\right.$ $<30^{\circ} \mathrm{C}$ ) gives

$$
\frac{d c_{q}}{d T_{c}}=0.0053 T_{c}+0.13 \quad[\mathrm{mg} / \mathrm{kg} / \mathrm{K}]
$$

This means that with a unitary temperature rise $\left(\Delta \mathrm{T}=1^{\circ} \mathrm{C}\right)$, a quartz-saturated solution can dissolve, in addition, almost $0.14 \mathrm{mg} / \mathrm{kg}$ at $0^{\circ} \mathrm{C}$ and $0.23 \mathrm{mg} / \mathrm{kg}$ at $20^{\circ} \mathrm{C}$, roughly 100 times less than the solubility increase in gypsum. It is thus possible to estimate that this speleogenetic process in quartzite is a hundred times slower than in gypsum (Table 1).

Sodium chloride solubility in water (Lide, 2007) can be interpolated by

$$
c_{h}=-1 \times 1^{-5} T_{c}^{3}+0.0042 T_{c}^{2}+0.0357 T_{c}+356,48 \quad \text { [g/kg] }
$$

It is easy to obtain an approximately linear temperature derivative (Fig. 7) in the $0<\mathrm{T}_{\mathrm{c}}<30^{\circ} \mathrm{C}$ range:

$$
\frac{d c_{h}}{d T}=7.5 T_{c}+38.7 \quad[\mathrm{mg} / \mathrm{kg} / \mathrm{K}]
$$

In this case, a unitary temperature rise $\left(\Delta \mathrm{T}=1^{\circ} \mathrm{C}\right)$ of sodium chloride saturated water can cause the additional dissolution, of almost $39 \mathrm{mg} / \mathrm{kg}$ at $0^{\circ} \mathrm{C}$ and $191 \mathrm{mg} / \mathrm{kg}$ at $20^{\circ} \mathrm{C}$, which is comparable with that of gypsum at low temperatures but becomes ten times larger at higher temperatures. By combining Eq. 1 with Eqs. 8 and 9, it is easy to estimate the dissolution rate per kilogram of flowing water in the phreatic flow for quartzite and halite:

$$
\begin{gathered}
\Delta c_{q}=\left(0.0053 T_{c}+0.13\right) \frac{500}{P_{i}}\left[\mathrm{mgkg}^{-1} \mathrm{a}^{-1}\right] \\
\Delta c_{h}=\left(7.5 T_{c}+38.7\right) \frac{500}{P_{i}}\left[\mathrm{mgkg}^{-1} \mathrm{a}^{-1}\right]
\end{gathered}
$$




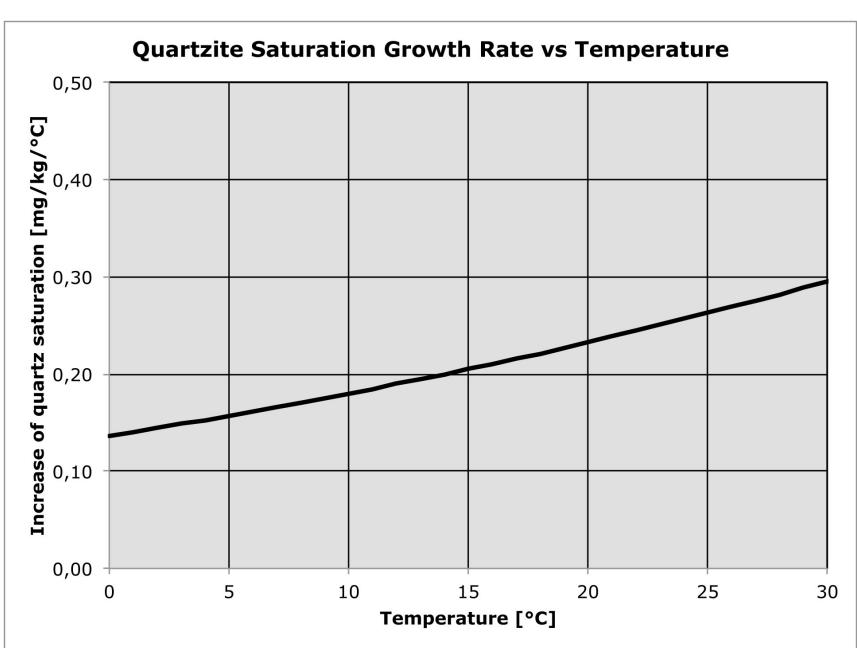

Fig. 6. Variation in quartzite saturation level as a function of temperature.

Table 1. Typical solubilities for the three rock in discussion.

\begin{tabular}{|l|c|c|c|c|}
\cline { 2 - 5 } \multicolumn{1}{c|}{} & Unit & Gypsum & Quartzite & Halite \\
\hline $\begin{array}{l}\text { Salt concentration at } \\
\text { saturation, T }=0{ }^{\circ} \mathrm{C}\end{array}$ & $\mathrm{mg} / \mathrm{kg}$ & 2,180 & 3.8 & 356,000 \\
\hline $\begin{array}{l}\text { Salt concentration at } \\
\text { saturation, T }=20^{\circ} \mathrm{C}\end{array}$ & $\mathrm{mg} / \mathrm{kg}$ & 2,560 & 7.4 & 359,000 \\
\hline $\begin{array}{l}\text { Saturation value } \\
\text { increase, } 0-1^{\circ} \mathrm{C}\end{array}$ & $\mathrm{mg} / \mathrm{kg}$ & 24.8 & 0.14 & 39 \\
\hline $\begin{array}{l}\text { Saturation value } \\
\text { increase, } 20-21^{\circ} \mathrm{C}\end{array}$ & $\mathrm{mg} / \mathrm{kg}$ & 13.9 & 0.23 & 192 \\
\hline $\begin{array}{l}\text { Geothermal dissolution } \\
\text { rate d (mass) at } 0^{\circ} \mathrm{C}\end{array}$ & $\mathrm{kg} \mathrm{m}^{-2} \mathrm{ka}^{-1}$ & 12 & 0.065 & 19 \\
\hline $\begin{array}{l}\text { Geothermal dissolution } \\
\text { rate d (mass) at } 20^{\circ} \mathrm{C}\end{array}$ & $\mathrm{kg} \mathrm{m}^{-2} \mathrm{ka}^{-1}$ & 17 & 0.118 & 95 \\
\hline
\end{tabular}

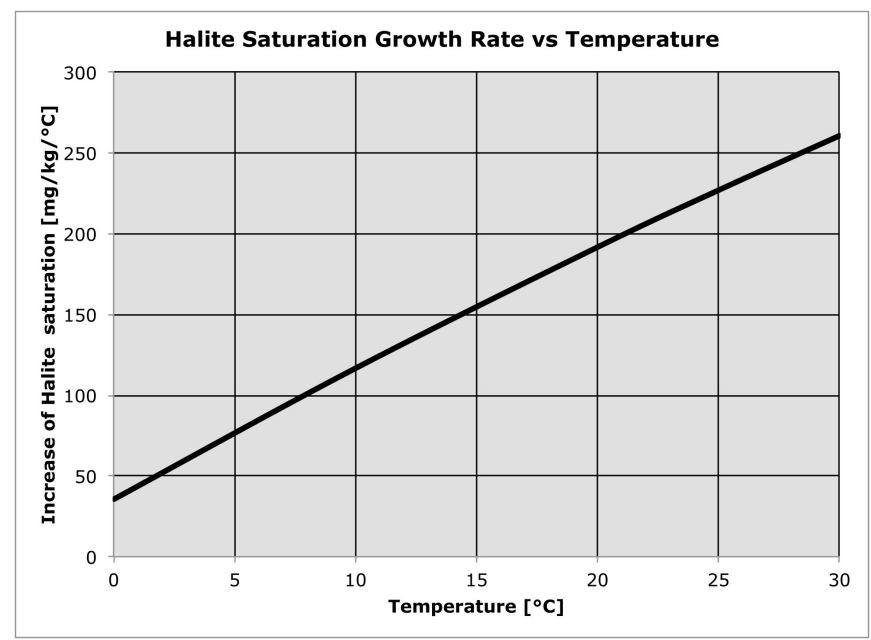

Fig. 7. Variation in halite saturation level as a function of temperature.

With the same typical values $\left(\mathrm{T}_{\mathrm{c}}=15^{\circ} \mathrm{C}, \mathrm{P}_{\mathrm{i}}=1,000 \mathrm{~kg}\right.$ $\mathrm{m}^{-2} \mathrm{a}^{-1}$ ) these equations yield dissolution rates around 0.1 (quartzite) and $75 \mathrm{mg} \mathrm{kg}^{-1} \mathrm{a}^{-1}$ (halite), i.e., amount of rock dissolved yearly per kilogram of underground flowing water. Table 1 gives examples of usual solubilities and solubility increases.

Multiplying both sides by $\mathrm{P}_{\mathrm{i}}$, the equation gives the dissolution rate per square meter of surface per year, which therefore does not depend on the precipitation. The equations suggest using a time period of a million years (Ma) for quartzite and a thousand years (ka) for halite, then:

$$
\begin{gathered}
d_{q}=P_{i} \Delta c_{q}=2.65 T_{c}+65 \quad\left[\mathrm{~kg} \mathrm{~m}^{-2} \mathrm{Ma}^{-1}\right] \\
d_{h}=P_{i} \Delta c_{h}=3.75 T_{c}+19.4 \quad\left[\mathrm{~kg} \mathrm{~m}^{-2} \mathrm{ka}^{-1}\right]
\end{gathered}
$$

It is possible to see that the amount of dissolution induced by geothermal flux at $10^{\circ} \mathrm{C}$ is around $90 \mathrm{~kg}$ per square meter per million years in quartzite and $60 \mathrm{~kg} / \mathrm{m}^{2} / \mathrm{ka}$ in halite.

\section{DISCUSSION}

\section{Dissolution intensity}

It is convenient to emphasize the experimental proofs of these calculations. There is direct evidence that:

1) Geothermal flux exists everywhere, albeit with regional variation of intensity (Davies, 2010).

1) Rocks situated above drained aquifers are "cold", i.e., in thermal equilibrium with the external atmosphere (Badino, 1995).

The First Law of Thermodynamics obviously applies also to the underground environment, and so these two statements provide direct evidence that flowing groundwater absorbs the geothermal energy flux and that it always gets warmer as it travels to the springs. Consequently, along its underground flow path in thermal contact with the HGB, saturated water departs from saturation equilibrium with regard to salt content, becoming aggressive (Fig. 8). The dissolution rate induced by geothermal flow at $10^{\circ} \mathrm{C}$ is $10 \mathrm{~kg} / \mathrm{m}^{2} / \mathrm{ka}$ in gypsum, $60 \mathrm{~kg} / \mathrm{m}^{2} / \mathrm{ka}$ in halite and $90 \mathrm{~kg} / \mathrm{m}^{2} /$ Ma in quartzite.

Table 2 gives the dissolution intensity per square kilometer per thousand years in these rocks. It is possible to see that there are orders of magnitude difference, but also that the dissolution is surprisingly high even for quartzite, where the involved time scales are hundreds of million years. The typical conduit density in alpine caves, in limestone, is around $10 \mathrm{~km} / \mathrm{km}^{2}$, i.e., some $10^{5} \mathrm{~m}^{3} / \mathrm{km}^{2}$ of voids. It is easy to see that the required time to attain similar densities by this process is quite short. One could gather that this speleogenetic process must be effective in

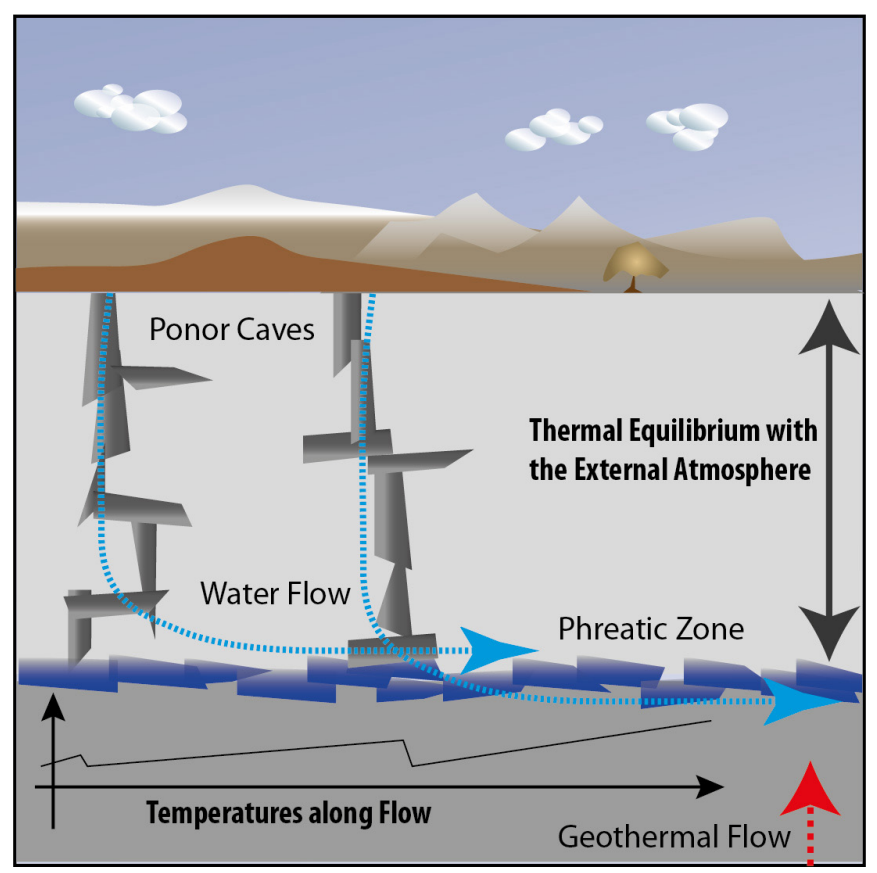

Fig. 8. Geothermal energy increases groundwater temperature along its flow to the spring, at the boundary between the Homothermic and Geothermal layers. 
Table 2. The dissolution rates for various rocks at $0^{\circ}$ and $20^{\circ} \mathrm{C}$, respectively.

\begin{tabular}{|l|c|c|c|c|}
\cline { 2 - 5 } \multicolumn{1}{c|}{} & Unit & Gypsum & Quartzite & Halite \\
\hline Geothermal dissolution rate (vol) at $0^{\circ} \mathrm{C}$ & $\mathrm{m}^{3} \mathrm{~km}^{-2} \mathrm{ka}^{-1}$ & 5,100 & 25 & 8,800 \\
\hline Geothermal dissolution rate at (vol) $20^{\circ} \mathrm{C}$ & $\mathrm{m}^{3} \mathrm{~km}^{-2} \mathrm{ka}^{-1}$ & 7,200 & 45 & 44,000 \\
\hline
\end{tabular}

any situation, although this does not exclude the possibility of other processes being active at the same time. Since this process is always active, it becomes clear that it can cause radical changes in the mountain morphology, well beyond the formation of caves.

\section{Boundary conditions}

Once water flow starts, in a diffuse or conduit form, the overlying rock mass inevitably cools down, creating a homothermic layer delimited below by flowing water. Dissolution and formation of caves then invariably begin. These processes are so intense that they can lead to the collapse of the entire drainage structure, destroying the very cavities they previously created. By increasing subterranean permeability, the speleogenetic process eventually facilitates water flow, but this flow must exist before the whole mechanism becomes active. In other words, it is a positive feedback process, which however does not predict the depth of the initial underground water drainage.

It is reasonable to relate such a beginning to the geological "boundary conditions", i.e., the previous history of the area. The local geological details (rock permeability and isotropy, presence of fractures, and so on) determine the subsequent formation of deep cave systems with the processes described.

\section{Caves}

In the case of gypsum, one could consider a surface $A$ of $1 \mathrm{~km}^{2}$ with $\mathrm{P}_{\mathrm{i}}=1,000 \mathrm{~mm} / \mathrm{a}$, at an average temperature of $10^{\circ} \mathrm{C}$ : in these conditions, the dissolution due to geothermal heating is 9 milligrams of gypsum per kilogram of flowing water. The global water flux through $\mathrm{A}$ is $10^{9} \mathrm{~kg}$ per year, and therefore the springs eject an additional $9,000 \mathrm{~kg}$ of calcium sulfate per year, i.e., around 4 cubic metres of rock removed each year from the lower parts of the drainage system in $\mathrm{A}$.

Caves such as Optymistychna or Ozernaja have around $100 \mathrm{~km}$ of conduits per square kilometer (Klimchouk, 1996b), with excavated volumes around $2-4 \times 10^{5} \mathrm{~m}^{3}$ along a single geologic horizon.

The dissolution processes induced by geothermal energy flow can dissolve these volumes in less than $10^{5}$ years. These caves are probably much older than this figure, which is simply the minimum time required to create them; in fact, the dissolution processes have to remove these rock volumes, but in doing so they do not necessarily create conduits accessible for human passage. It is possible to make the same estimation for halite, with a dissolution rate strongly increasing with temperature but six times larger than the one for gypsum at $10^{\circ} \mathrm{C}$. This means that, under these conditions, the genesis of caves is six times faster than in gypsum.

In quartzite, the process is roughly 100 times slower than in gypsum $\left(90 \mathrm{~kg} / \mathrm{m}^{2} / \mathrm{Ma}\right)$, and the time scale of cave formation can become so slow as to be comparable with the orogenic time scale. Furthermore, when dealing with such an extended time frame a discussion about the "initial" conditions of water drainage can become impossible. Nevertheless, large caves with average dissolved volumes of some cubic meters of rock per square meter of external surface can form in a few tens of millions of years, a relatively short time for the Amazonian tepui (Sauro, 2013; Mecchia et al., 2014).

\section{Mining}

The geothermal energy flow is then able to "reactivate" infiltrated water that was originally saturated with salts, and can then keep it corrosive throughout its journey underground. This is particularly evident and fast if the water drainage network has been artificially moved downward by mining activities, because occult water drainage networks can be quickly formed, secondarily to the excavation works.

Lucha (2008) has described the rapid formation of large caves in halite after important changes to the landscape, linked to mining activities, which led to the infiltration of meteoric, unsaturated waters. After the first phase of saturation, they probably maintained aggressiveness by geothermal heating and have created drainage networks exceeding $1 \mathrm{~km}$ in length.

Another case in which mining activity in gypsum has intercepted water flow into a cave, is in the Spipola Cave, near Bologna (Italy). In the 1980s a gypsum quarry lowered the cave base level, by about $15 \mathrm{~m}$, which had been stable for 2000 years. As a result, in less than 30 years a lower drainage level developed that was capable of absorbing all the water flux for a length of nearly $1 \mathrm{~km}$, initially with a retrograde progression speed of about $50 \mathrm{~m} / \mathrm{a}$ (Forti, 2003). The catchment area of the cave is $0.58 \mathrm{~km}^{2}$, with an average rainfall of $760 \mathrm{~mm} / \mathrm{a}$. Including the contribution of internal condensation and evapotranspiration, it is possible to estimate an average water flow of $10 \mathrm{~L} / \mathrm{s}$. The lowering of the drainage level has caused the intersection of rocks $0.5^{\circ} \mathrm{C}$ warmer (a rough estimate for a similar shallow situation), which has resulted in an increase in dissolution of about $10 \mathrm{mg} / \mathrm{L}$. This implies dissolution of about $3,000 \mathrm{~kg} / \mathrm{a}$, with approximately $1.5 \mathrm{~m}^{3}$ of dissolved gypsum.

In conclusion, we can state that the mining activities, by lowering the zone of active drainage, can create conduit systems, which did not exist before. This is why it is necessary not to assume that salt mines, by their impervious lithology, are suitable for waste storage, because the conduit excavation (for mining or for waste storage construction) may trigger the formation of a drainage network discharging outside the site area.

\section{Local processes}

The dissolution processes caused by geothermal flux can be discussed for their local effects, as given 
by the average dissolution rate yielded by Eq. 5, 10, and 11 . It is sufficient to deal with the gypsum case, because simple scaling gives the values for halite and quartzite, as described above. It has been shown that at an average temperature of $10^{\circ} \mathrm{C}$ the global rate of dissolution is about $15 \mathrm{~kg} / \mathrm{m}^{2} / \mathrm{ka}$, averaged over the whole drainage surface, a surprisingly high value. During $10^{5}$ years, a reasonable time scale for a cave to evolve in gypsum (Columbu, 2015), it corresponds to $0.6 \mathrm{~m}^{3}$ of rock removed in the deepest layers by flowing groundwater per square meter of the system's surface area.

As noted before, on a large scale this process can be viewed as homogeneous, but on a smaller scale (local) the corrosion is expected to increase rock permeability, thereby concentrating the water flow along the opened passages. It is therefore reasonable to expect gypsum dissolution to evolve from draining a fissure network to developing a conduit network of increasing size, which eventually will collapse due to the weight of overlying rocks. Dissolution will then continue in a zone of collapsed rock, insoluble mud and small passages. The speleogenetic process is concentrated where the water gets warmed up, i.e., around the flow line with maximum geothermal heat absorption, which corresponds also to the main lines of flow, in contact with the lower boundary of the homothermic layer.

\section{Conduit shapes}

This can give us some morphological constraints that are useful for verifying this speleogenetic mechanism. This excavation process is definitely active if flowing water absorbs the geothermal flux in the lower parts of conduits (Figs. 9, 10). On the other hand, in several instances this latter can be shielded, thereby preventing any dissolution. If, for instance, below the gypsum deposit there is a deeper, drained water table, the whole system lies in a "geothermal shadow", where no water heating can take place and therefore the speleogenetic process cannot be active. This means that the excavation rate by this mechanism in the rocks above existing drainage conduits is zero, and we expect a bi-dimensional shaped network of conduits, flattened above the HGB and with complete suppression of overlying passages, which cannot be formed and evolve at the same time as the main network. Obviously, such higher conduits can still be found, as they can have formed at different times.

\section{Temperature dependence}

This process is strongly temperature-dependent, not only because it is more efficient at low temperature (for gypsum, whose solubility rate decreases by $50 \%$ from 0 to $20^{\circ} \mathrm{C}$; the contrary is true for halite and quartzite), but also because conductive thermal exchange is temperature-dependent, too. A $\mathrm{T}=4^{\circ} \mathrm{C}$ temperature is a pivotal turning point for these processes.

In fact, water heating is controlled by very small temperature differences between rock and water, and it has extremely complex characteristics. At $4^{\circ} \mathrm{C}$ fresh water attains its maximum density and

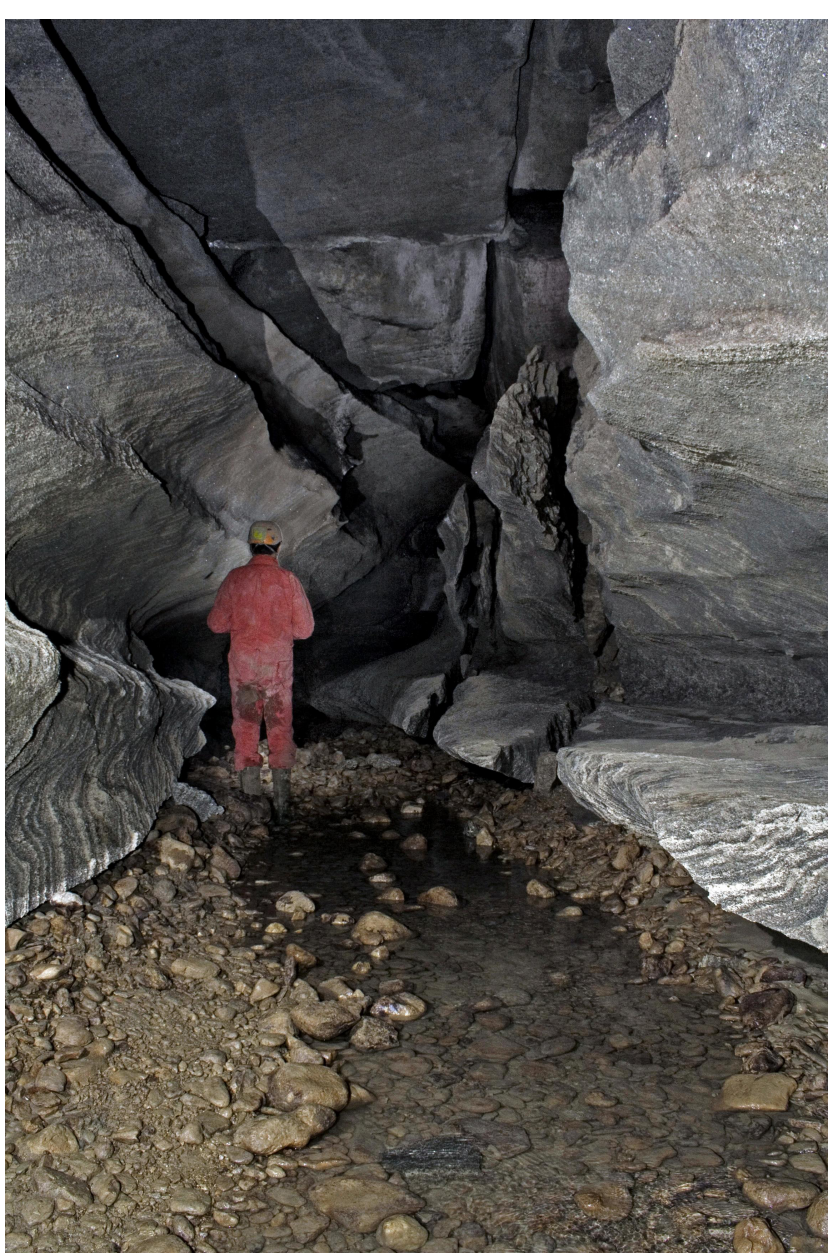

Fig. 9. Conduit in Rio Basino Cave, near Bologna (Italy).

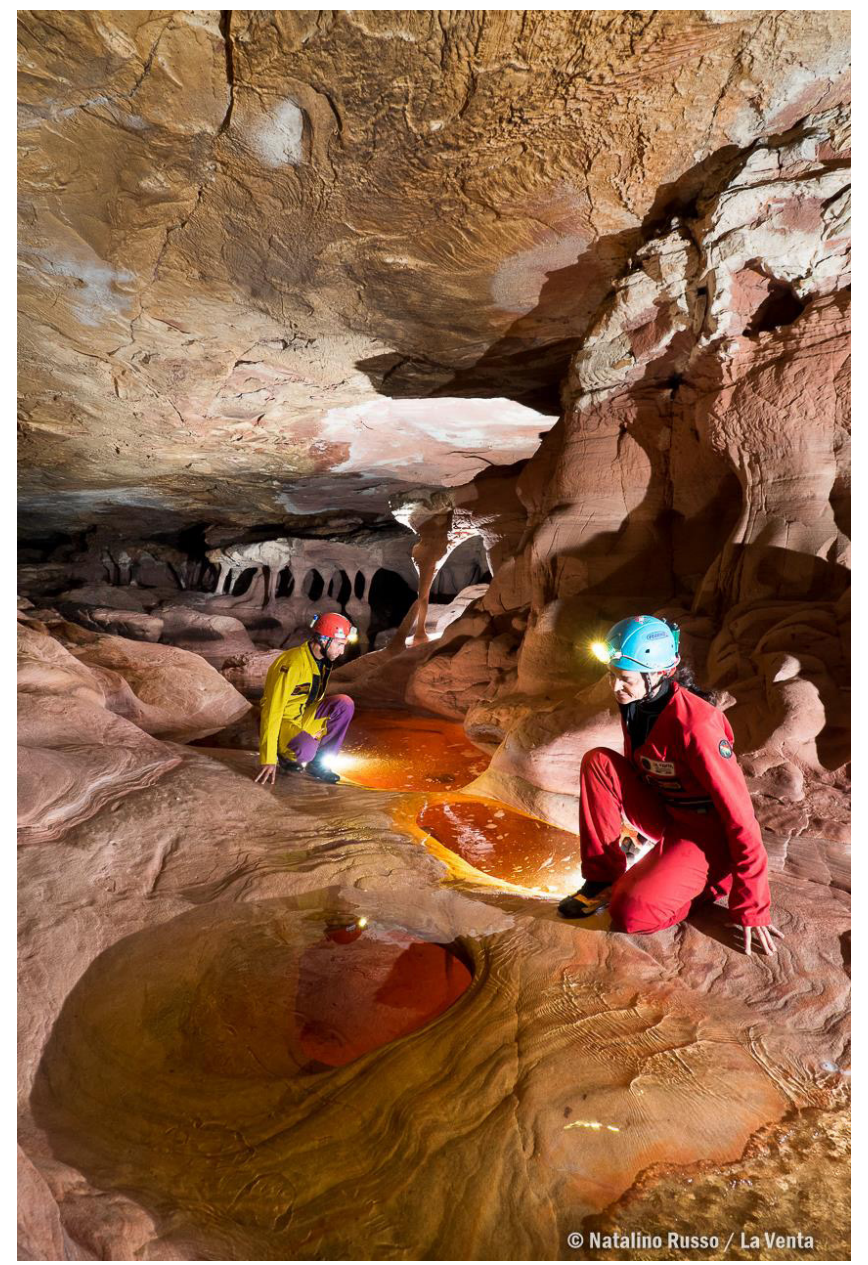

Fig. 10. Conduit in Imawari Yeuta, Venezuela. 
usually its convective pattern changes completely. Above this critical temperature the water, heated by contact with the geothermal layer, rises and generates a mixing pattern of eddies. Below this temperature, the heated water is trapped against the floor and the system tends to attain local thermal stability. In the first case dissolution extends along the whole length of the drainage conduit, whereas in the second it is concentrated in its lower parts.

\section{Mixing waters}

The rate of water infiltration strongly depends on time and climate, and so does the underground water flow. As usual in cave physics, these thermo-kinetic processes are not stationary, but fluctuate around an equilibrium level. In the case of cave micrometeorology, these small fluctuations are responsible for many fundamental processes (condensation and airflow), which eventually determine cave morphology (Badino, $2005 b)$. It is possible to estimate their role in this case, with a brief discussion about mixing of saturated water at different temperatures.

The solubility function $\mathrm{c}_{\mathrm{g}}$ (Eq. 2) is concave downward (its second derivative is negative), hence mixing two gypsum-saturated water parcels of different temperature generates an unsaturated water body, as in the mixing corrosion model of Bögli (1980). It is easy to estimate the under-saturation level produced by mixing two parcels of the same mass. Final concentration and temperature are the average of the two, hence (Fig. 11):

$$
c(T)-\frac{c\left(T_{1}\right)+c\left(T_{2}\right)}{2}=-\frac{1}{8}\left(T_{2}-T_{1}\right)^{2}\left[\frac{d^{2} c(T)}{d T^{2}}\right]_{T_{1}}
$$

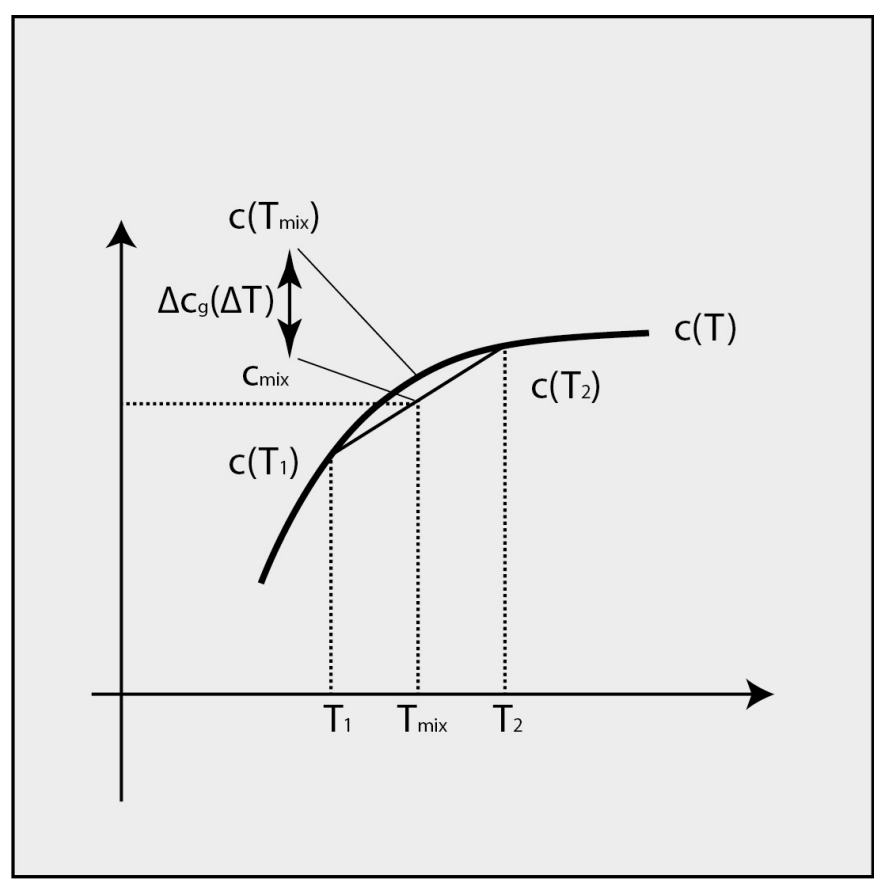

Fig. 11. Undersaturation due to mixing of two water bodie, of the same mass, at different temperatures.

From Eq. 3 we have the second derivative of $c_{g}(T)$, then the undersaturation of the final mass (Fig. 12) is described by:

$$
\Delta c_{g}(\Delta T)=6.48 \times 10^{-2}(\Delta T)^{2} \quad\left[\mathrm{mg} \mathrm{kg}^{-1}\right]
$$

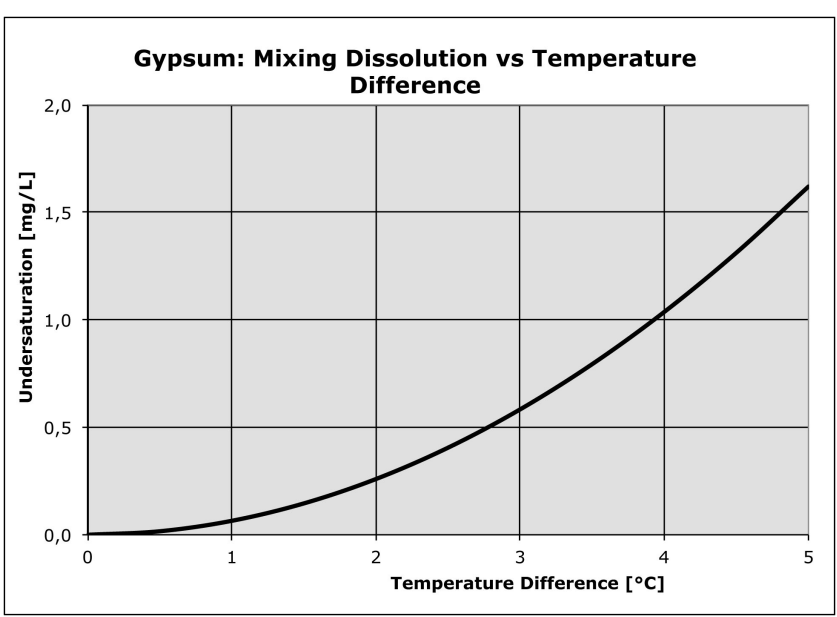

Fig. 12. Undersaturation of gypsum due to mixing of two water particles, of the same mass, as a function of their temperature difference.

The system temperature is not uniform, and dissolution is probably concentrated where (and when) conduit morphology mechanically forces the "hot" and saturated waters to mix with the upper layers. Some underground water bodies can remain for months almost motionless, exposed to geothermal heating, then move away when the water flow regime changes. Total enthalpy release obviously remains the same, as does the dissolved gypsum mass, but the heating rate is not constant, and it concentrates on different parts of the water body depending also on water mixing. Preferred zones of excavation are thus located where speed and turbulence of the water are highest, i.e., where conduit sections are smaller. In contrast, excavation becomes slower where flow velocity is reduced, i.e., where conduit sections are larger or within blind branches. At any rate, the total mass of dissolved salt has to remain constant, as it is proportional to the invariable geothermal energy released to water (Eq. 5).

\section{Conduit evolution}

It is possible to conclude with some comments about the long-term evolution of conduits. An important timedependent term is the permeability of the drainage network. The dissolution processes tend to widen and deepen the conduits, slowly lowering the boundary of thermal exchange (HGB). Another process is at play as well, namely sediment deposition. Rock dissolution usually releases insoluble components, which can fill the lower parts of drainage conduits, moving the HGB upwards and, with it, thermal exchanges and rock dissolution. This is a process somewhat similar to paragenesis in epigenic cave systems (Pasini, 2009).

\section{Paleo-climatic proxies}

Finally it could be noted that, due to the strong dependence of these speleogenetic processes on temperature and precipitation, global climatic changes have amplitudes that are clearly able to modulate the evolution of conduits. It is possible to look for their signature in gypsum and, above all, in halite. It is instead unlikely that the long time-scale of quartzite cave evolution would allow external, "quickly" changing climate to leave any deep signature upon these "ultra-slow" underground systems. 


\section{CONCLUSIONS}

Geothermal energy, which in geological times has heated the depths of the Earth's crust, eventually emerges at the surface, with complex characteristics in the "last kilometre". The uppermost underground layers are in fact in thermal contact with the external atmosphere due to water that infiltrates underground. The groundwater flowing at the base of this superficial layer is exposed to the geothermal energy, so that the water temperature increases at a rate inversely proportional to the amount of infiltration.

Within soluble rocks, this heating unbalances the chemistry of salts already dissolved in the water, which in general had previously attained equilibrium along its descent into the aquifer; the result depends on the details of the physical-chemical conditions of the whole environment, and in carbonate rocks the outcome is generally very complex. If the rocks conducting drainage to depth are gypsum, halite or quartzite, the process becomes much simpler; water becomes unsaturated due to an increase in temperature and it dissolves rock as it flows to the spring. This unavoidable speleogenetic process is proportional to the intensity of local geothermal energy flux; it is more efficient at low temperatures in gypsum, while the opposite is true for quartzite and, especially, halite. The estimated speed of these processes occurring at the points of contact between homothermic and geothermal layers seems adequate to explain the formation of large phreatic caves in these rocks.

\section{ACKNOWLEDGEMENTS}

The author thanks those who helped to improve the original manuscript, in particular José Maria Calaforra, Arrigo Cigna, Jo De Waele, Paolo Forti and Fernando Gasquez Sanchez for helpful comments and discussions, Antonio De Vivo, and Libero Vitiello for revision of the manuscript.

\section{SYMBOLS}

HHB: Heterothermic-Homotermic Boundary

HGB: Homotermic and Geothermal Layer

$\mathrm{T}_{\text {ave }}$ : Local average yearly temperature

$\mathrm{T}_{\mathrm{aw}}$ : Local average yearly temperature of water infiltration

$\mathrm{F}_{\mathrm{gt}}$ : Local geothermal flux

$\mathrm{C}_{\mathrm{w}}$ : $\quad$ Specific thermal capacity of water $\left(\mathrm{J} \mathrm{kg}^{-1} \mathrm{~K}^{-1}\right)$

$\mathrm{P}_{\mathrm{i}}$ : $\quad$ Average local water infiltration flux $\left(\mathrm{kg} \mathrm{m}^{-2} \mathrm{~s}^{-1}\right)$

$\Delta \mathrm{T}_{\mathrm{gt}}: \quad$ Water temperature increase along the phreatic flow path (K)

$\mathrm{T}(\mathrm{x}, \mathrm{y}, \mathrm{z})$ : Subterranean temperature field

$\mathrm{T}_{\mathrm{c}}$ : $\quad$ Water temperature $\left({ }^{\circ} \mathrm{C}\right)$

$\mathrm{c}_{\mathrm{g}}, \mathrm{c}_{\mathrm{q}}, \mathrm{c}_{\mathrm{h}}$ : gypsum, quartzite, and halite solubility in water at saturation ( $\mathrm{mg} \mathrm{kg}^{-1}$ )

$\mathrm{dc}_{\mathrm{g}} / \mathrm{dT}, \mathrm{dc}_{\mathrm{q}} / \mathrm{dT}, \mathrm{dc}_{\mathrm{h}} / \mathrm{dT}$ : gypsum, quartzite, and halite solubility variation with temperature, in water at saturation $\left(\mathrm{mg} \mathrm{kg}^{-1}\right)$

$\Delta \mathrm{c}_{\mathrm{g}}, \Delta \mathrm{c}_{\mathrm{q}}, \Delta \mathrm{c}_{\mathrm{h}}:$ gypsum, quartzite, and halite dissolution rate per kilogram of flowing phreatic water $\left(\mathrm{mg} \mathrm{kg}^{-1} \mathrm{a}^{-1}\right.$ ) $\mathrm{d}_{\mathrm{g}}, \mathrm{d}_{\mathrm{h}}$ : gypsum and halite dissolution rates per square meter $\left(\mathrm{kg} \mathrm{m}{ }^{-2} \mathrm{ka}^{-1}\right)$

$\mathrm{d}_{\mathrm{q}}$ : quartzite dissolution rate per square meter $\left(\mathrm{kg} \mathrm{m} \mathrm{m}^{-2} \mathrm{Ma}^{-1}\right)$

\section{REFERENCES}

Babkin V.I., 2003 - The Earth and its physical features. In: Shiklomanov I.A. \& Rodda J.C. (Eds.), World water resources at the beginning of the twenty-first century. International Hydrology Series, Cambridge University Press, p. 1-18.

Badino G., 1995 - Fisica del clima sotterraneo. Memoria dell'Istituto Italiano di Speleologia, II (7): 1-137.

Badino G., 2004 - Cave temperatures and global climatic change. International Journal of Speleology 33: 103-113. https://doi.org/10.5038/1827-806X.33.1.10

Badino G., 2005a - Underground drainage systems and Geothermal Flux. Acta Carsologica, 34 (2): 277-316. https://doi.org/10.3986/ac.v34i2.261

Badino G., 2004 - Clouds in caves. Speleogenesis and Evolution of Karst Aquifers, 2 (6): 1-2. http://www.speleogenesis.info/directory/karstbase/ publication.php?id=4499

Badino G., 2010 - Underground Meteorology, What's the weather underground? Acta Carsologica, 39 (3): 427-448. https://doi.org/10.3986/ac.v39i3.74

Bejan A., 1993 - Convection heat transfer. John Wiley and Sons, Hoboken, 696 p.

Bögli A., 1980 - Karst hydrology and physical speleology. Springer, Berlin, 284 p. https://doi.org/10.1007/978-3-642-67669-7

Celico P., 1986 - Prospezioni idrogeologiche. Liguori, Napoli, 528 p.

Cohen P., 1989 - The ASME handbook on water technology for thermal power systems. In: Cohen P. (Ed.), American Society of Mechanical Engineers, 1828 p.

Columbu A., De Waele J., Forti P., Montagna P., Picotti V., Pons-Branchu E., Hellstrom J., Bajo P. \& Drysdale R., 2015 - Gypsum caves as indicators of climate-driven river incision and aggradation in a rapidly uplifting region. Geology, 43 (6): 539-542.

https://doi.org/10.1130/G36595.1

Crestani G. \& Anelli F., 1939 - Ricerche di meteorologia ipogea nelle grotte di Postumia, Publicazione N. 143 del Magistrato alle Acque di Venezia, Ufficio idrografico, XVII, Roma, 162 p.

Davies J.H. \& Davies D.R., 2010 - Earth's surface heat flux. Solid Earth, 1: 5-24. https://doi.org/10.5194/se-1-5-2010

Dublijanski V.N. \& Sockova L.M., 1977 - Microclimate of karst cavities of the Mountain of Crimea, Proceedings of the $7^{\text {th }}$ International Congress of Speleology, Sheffield, UK, pp. 158-160.

Forti P., 2003 - I sistemi carsici. in Biancotti A., Motta M., - Risposta dei processi geomorfologici alle variazioni ambientali. Briganti, Genova, p. 246-251.

Guichonnet P., 1967 - Il Traforo del Monte Bianco. Mondadori, Milano, 360 p.

Isachenko V., Osipova V. \& Sukomel A., 1969 - Heat transfer. Mir Publishers, $552 \mathrm{p}$.

Klimchouk A., 2012 - Krubera (Voronja) Cave. In: White W.B. \& Culver D.C. (Eds.), Encyclopedia of caves $\left(2^{\text {nd }}\right.$ Ed.), Academia Press, New York, pp. 443-450. https://doi.org/10.1016/B978-0-12-383832-2.00063-3

Klimchouk A., 1996b - Gypsum karst in the Western Ukraine. International Journal of Speleology, 25 (3-4): 263-278. https://doi.org/10.5038/1827-806X.25.3.20 
Klimchouk A., 1996 - Dissolution and conversions of gypsum and anhydrite. In: Klimchouk A.B., Ford D.C., Palmer A.N. \& Dreybrodt W. (Eds.), Speleogenesis. Evolution of karst aquifers. National Speleological Society, Huntsville, AL, pp. 160-168.

https://doi.org/10.5038/1827-806X.25.3.2

Lide D., 2007 - Aqueous solubility of inorganic compounds. CRC Handbook of Chemistry and Physics (88 ${ }^{\text {th }}$ Ed.), $2640 \mathrm{p}$.

Lucha P., Cardona F., Gutiérrez F. \& Guerrero J., 2008 Natural and human-induced dissolution and subsidence processes in the salt outcrop of the Cardona Diapir (NE Spain). Environmental Geology, 53: 1023-1035. https://doi.org/10.1007/s00254-007-0729-3

Luetscher M. \& Jeannin P., 2004 - Temperature distribution in karst systems: the role of air and water fluxes. Terra Nova, 16: 344-350.

https://doi.org/10.1111/j.1365-3121.2004.00572.x

Mathey B., 1974 - Gradient géothermique et hydraulique souterraine dans un aquifère karstique (Bassin de l'Areuse, $\mathrm{Ne}$ ). Bulletin de la Société Neuchâteloise des Sciences Naturelles, 97: 301-314.

Mecchia M., Sauro F., Piccini L., De Waele J., Sanna L., Tisato N., Lira J. \& Vergara F., 2014 - Geochemistry of surface and subsurface waters in quartz-sandstones: significance for the geomorphic evolution of tepui table mountains (Gran Sabana, Venezuela). Journal of Hydrology, 511: 117-138.

https://doi.org/10.1016/j.jhydrol.2014.01.029
Newman E.S. \& Wells L.S., 1938 - Heats of hydration and transition of calcium sulfate. Journal of Research of the National Bureau of Standards, 20: 825-836. https://doi.org/10.6028/jres.020.004

Nashchokin V., 1979 - Engineering thermodynamics and heat transfer. Mir Publishers, $496 \mathrm{p}$.

Pasini G., 2009 - A terminological matter: paragenesis, antigravitative erosion or antigravitational erosion? International Journal of Speleology, 38: 129-138. https://doi.org/10.5038/1827-806X.38.2.4

Sauro F., 2014 - Structural and lithological guidance on speleogenesis in quartz-sandstone: Evidence of the arenisation process - Geomorphology, 226: 106-123. https://doi.org/10.1016/j.geomorph.2014.07.033

Sendra A. \& Reboleira A.S.P., 2012 - The world's deepest subterranean community-Krubera-Voronja Cave (Western Caucasus). International Journal of Speleology, 41 (2): 221-230. https://doi.org/10.5038/1827-806X.41.2.9

Shiklomanov N. \& Nelson F., 2013 - Thermokarst and civil infrastructure. In: Shroeder J.F. (Ed.), Treatise on Geomorphology: 354-373.

https://doi.org/10.1016/B978-0-12-374739-6.00216-5

Tikhomirov V.V., 2016 - Hydrogeochemistry fundamentals and advances. Wiley-Scrivener, New Jersey, Vol. 1, 312 p.

Verma M., 2000 - Revised quartz solubility temperature dependence equation along the water-vapor saturation curve. Proceedings of the World Geothermal Congress, Kyushu - Tohoku, Japan, May 28 - June 10, 2000, p. 1927-1932. 